\title{
Direct Action of Rat Urinary Kallikrein on Rat Kidney to Release Renin
}

\author{
S. Suzuki, R. Franco-Saenz, S. Y. Tan, and P. J. Mulrow, Department of \\ Medicine, Medical College of Ohio, Toledo, Ohio 43699
}

A B S T RACT To study the effect of kallikrein on renal renin release, we superfused rat renal cortical slices with 3.5 to 140 milliesterase units $(\mathrm{mEU}) / \mathrm{ml}$ of purified rat urinary kallikrein. Kallikrein was a potent stimulus of renin release. Renin rose in a dosedependent fashion from $70 \mathrm{mEU} / \mathrm{ml}$ to $140 \mathrm{mEU} / \mathrm{ml}$. The response to $140 \mathrm{mEU} / \mathrm{ml}$ was greater than that seen with maximal doses of prostaglandin $\mathrm{E}_{2}(170 \pm 43 \%$, $P<0.05)$ and at least the same as isoproterenol (242 $\pm 49 \%$ increase), or dibutyryl cyclic AMP $(272 \pm 40 \%)$. Trypsin was ineffective under these experimental conditions. Kallikrein-stimulated renin release was completely abolished by trasylol, whereas bradykinin did not increase renin production, indicating that kallikrein's effect is not mediated via kinin generation. There was no demonstrable acid activation or kallikrein activation of the superfusate and chromatography on Sephacryl S-200 revealed a single renin peak of $\sim 40,000 \mathrm{~mol} w \mathrm{w}$, suggesting that all of the renin release was in the active form. The data suggests that urinary kallikrein acts directly on the rat kidney to release renin, possibly via proteolytic conversion of prorenin to active renin. Our results support the concept that kallikrein may be an endogenous activator of prorenin in the kidney.

\section{INTRODUCTION}

Both the renin-angiotensin system and the kallikreinkinin system have been implicated in the control of sodium and water excretion, blood pressure regulation, and renal hemodynamics.

These two systems are interrelated in that renal kallikrein, via kinin generation, stimulates the production of prostaglandin $(1,2)$, which in turn, increases renin release (3-5). Furthermore, recently Sealey et al. (6) have reported that human urinary kallikrein converts plasma inactive renin to active renin. Because

\footnotetext{
Address reprint requests to Dr. Suzuki.

Received for publication 19 November 1979 and in revised form 24 April 1980.
}

renal kallikrein is produced in the renal cortex (7-9), especially in tubular cells $(9,10)$, it has been proposed that kallikrein may be the endogenous renin activator in the kidney. Direct action of renin stimulation by kallikrein has not been reported. The present study was carried out to evaluate the role of renal kallikrein on renin release.

\section{METHODS}

Isolation of rat urinary kallikrein. The isolation of rat urinary kallikrein (RUK) ${ }^{1}$ was based on the report of Nustad and Pierce (11). A 24-h urine collection was made from 50 female Sprague-Dawley rats, and dialyzed against distilled water at $4^{\circ} \mathrm{C}$ for $2 \mathrm{~d}$. It was then lyophilized, resuspended

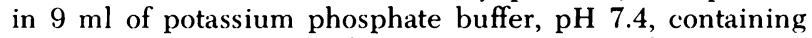
$0.2 \mathrm{M} \mathrm{KCl}$, and applied to a DEAE-Sephadex column $(3.5 \times 10 \mathrm{~cm})$. The column was washed with 1.5 column vol of $0.01 \mathrm{M}$ potassium phosphate buffer $\mathrm{pH} 7.4$ containing $0.2 \mathrm{M}$ $\mathrm{KCl}$. The column was then eluted with a linear gradient of $\mathrm{KCl}$ from 0.2 to $0.7 \mathrm{M}$ in $0.01 \mathrm{M}$ potassium phosphate buffer, $\mathrm{pH}$ 7.4. To locate the kallikrein fraction, aliquots of $200 \mu \mathrm{l}$ from each of the 6-ml fractions were assayed for $\alpha-N-P$ tosyl-L-arginine methyl ester (TAME) esterase activity. After the DEAE-Sephadex column chromatography, the active kallikrein fractions were pooled, dialyzed against distilled water at $4^{\circ} \mathrm{C}$ for $24 \mathrm{~h}$, lyophilized, and resuspended in $2 \mathrm{ml}$ of $0.05 \mathrm{M}$ Tris-Cl buffer, pH 8.0 , containing $0.05 \mathrm{M} \mathrm{NaCl}$ and $0.2 \% \mathrm{NaN}_{3}$. This sample was applied to a Sephacryl S-200 column $(1.5 \times 90 \mathrm{~cm}$; void volume $56.7 \mathrm{ml})$. The column was eluted with $0.05 \mathrm{M}$ Tris- $\mathrm{Cl}$ buffer, $\mathrm{pH}$ 8.0, which also contained $0.05 \mathrm{M} \mathrm{NaCl}$ and $0.2 \% \mathrm{NaN}_{3}$ at a flow rate of $10 \mathrm{ml} / \mathrm{h}$. 2 -ml fractions were collected and assayed for TAME esterase activity.

Kallikrein assay. Esterolytic activity of the kallikrein fraction was measured using the proteinase substrate $\mathrm{HCl}$ TAME. The unhydrolyzed ester was measured by the Roberts colorimetric method (12).

Kininogenase assays. Urinary kallikrein samples that had been isolated from rat urine were also assayed for kininogenase activity by the method of Nustad et al. (13). Dog plasma was used as a source of kininogen. A $250-\mathrm{ml}$ sample of dog blood was collected into $100 \mathrm{ml}$ of $1.32 \%$ sodium citrate. The plasma was separated by centrifugation, heated by $60^{\circ} \mathrm{C}$ for $30 \mathrm{~min}$,

\footnotetext{
${ }^{1}$ Abbreviations used in this paper: KRBG, Krebs-Ringer bicarbonate glucose buffer; $m E U$, milliesterase units; RUK, rat urinary kallikrein; TAME, $\alpha-N$-P-tosyl-L-arginine methyl ester.
} 
and dialyzed extensively against distilled water at $4^{\circ} \mathrm{C}$. The dog plasma preparation at a dilution of $1: 2$ was incubated with each kallikrein test samples at $30^{\circ} \mathrm{C}$ for $3 \mathrm{~min}$. The kinin generated was then bioassayed by adding an aliquot of the mixture, exactly at the end of the incubation time, to a rat uterus in a muscle chamber containing modified Krebs bicarbonate media (de Jalon solution), gassed with $95 \% \mathrm{O}_{2}, 5 \%$ $\mathrm{CO}_{2}$, and the uterine contractile response was measured by glass transducer $\mathrm{FTO}_{3}$ and recorded in a physiograph recorder (Hewlett-Packard 7702B, Hewlett-Packard Co., Palo Alto, Calif.). The preparation was standardized with synthetic bradykinin and the results were expressed in terms of micrograms of bradykinin generated per minute.

Superfusion of rat renal cortical slices. Sprague-Dawley female rats weighing 200-250 g were used for the experiments. The rats were maintained on a regular Purina Rat Chow $\operatorname{diet}$ (Ralston Purina Co., St. Louis, Mo.) and were anesthetized with sodium pentobarbital $(50 \mathrm{mg} / \mathrm{kg}$ i.p.), and decapitated. The kidneys were quickly removed, decapsulated, and placed in a Stadie-Riggs microtome. One renal cortical slice, $\sim 0.3-$ $0.5 \mathrm{~mm}$ in thickness, was obtained from the ventral and another from the dorsal surface of each kidney. $60-80 \mathrm{mg}$ $(\sim 1.5$ slices) of renal cortical tissue was placed in the middle of two O-ring joints that contained a small plastic filter in one side to prevent displacement of the tissue after the superfusion was started. The two O-ring joints were held together by a clamp and the two ends of it were connected with polyethylene tubing (PE 280) with an interior diameter of $2.15 \mathrm{~mm}$. The tissue holder was placed in a water bath at $37^{\circ} \mathrm{C}$ and the tissue was perfused with Krebs-Ringer bicarbonate, glucose buffer (KRBG), pH 7.4, containing $\mathrm{Na}^{+}, 144 \mathrm{mM} ; \mathrm{K}^{+}, 4.7 \mathrm{mM}$; $\mathrm{Ca}^{++}, 2.7 \mathrm{mM} ; \mathrm{Cl}^{-}, \mathrm{HCO}_{3}^{-}, 25 \mathrm{mM} ; \mathrm{Mg}^{++}, 1.2 \mathrm{mM} ; \mathrm{H}_{2} \mathrm{PO}_{4}^{-}$, $1.2 \mathrm{mM}$; glucose, $11 \mathrm{mM}$, which is continuously bubbled with a mixture of $95 \% \mathrm{O}_{2}$ and $5 \% \mathrm{CO}_{2}$. The polyethylene tubing passed through a peristaltic pump. The tubing was connected to a warming coil and a debubbler before reaching the tissue. The efferent end of the tubing was connected to a fraction collector. The dead space of the whole system was $\sim 10 \mathrm{ml}$ and the flow rate was $1 \mathrm{ml} / \mathrm{min}$. The initial $75 \mathrm{~min}$ of superfusion with KRBG were discarded.

After a 60-min perfusion to obtain a stable base line, a control sample was collected over a 20 -min period (period 1) (Fig. 3). The stimulating agent was dissolved in $30 \mathrm{ml}$ of $\mathrm{KRBG}$ and superfused over $30 \mathrm{~min}$. The experimental sample was collected during the last $20 \mathrm{~min}$ after application of the stimulus (period 2). The superfusate was changed to the control KRBG and the next control sample was obtained during the last $20 \mathrm{~min}$ of the 30 -min control superfusate (period 3). The above schedule was repeated two to three times. Experiments were performed with $3.5-140 \mathrm{mEU} / \mathrm{ml}$ of RUK, $0.1 \mu \mathrm{M}-0.1 \mathrm{mM}$ of bradykinin (Sigma Chemical Co., St. Louis, Mo.), $1 \mathrm{nM}-6 \mu \mathrm{M}\left(23\right.$ to $\left.138 \times 10^{3} \mathrm{mEU} / \mathrm{ml}\right)$ of trypsin, 472 kallikrein inhibiting units $/ \mathrm{ml}(\mathrm{KIU} / \mathrm{ml})$ of trasylol, $0.8 \mu \mathrm{M}$ of isoproterenol, $5 \mathrm{mM}$ of dibutyryl cyclic AMP (all from Sigma Chemical Co.), and $0.1 \mathrm{mM}$ of prostaglandin $\mathrm{E}_{2}$ (Upjohn Co., Kalamazoo, Mich.). Separate tissues were superfused with each stimulus and replicated experiments $(n=4)$ were performed. To investigate the possibility of tissue damage by kallikrein, the enzymes glutamic oxaloacetic transaminase and $\gamma$-glutamyl transpeptidase were measured in control and kallikrein-stimulated samples by previously described methods $(14,15)$. To determine whether kallikrein would activate renin in vitro, kallikrein was added directly to control superfusate and incubated for $1 \mathrm{~h}$ at $25^{\circ} \mathrm{C}$.

Renin measurements. $50 \mu \mathrm{l}$ of superfusion samples were incubated with $75 \mu \mathrm{l}$ of nephrectomized rat plasma, $90 \mu \mathrm{l}$ of Tris-acetate-lysozyme buffer, pH 7.4, $25 \mu$ l of $4 \%$ EDTA, $5 \mu \mathrm{l}$ of Dimercaprol, and $5 \mu \mathrm{l}$ of 8-hydroxyquinoline. Incubation was for $3 \mathrm{~h}$ at $37^{\circ} \mathrm{C}$ after which samples were transferred to an ice bath, $50-\mu$ l aliquots were taken for radioimmunoassay of generated angiotensin I (Becton, Dickinson Co., Renin Kit). The interassay coefficient of variation using superfusate samples was $11.5 \%(n=10)$ and the intraassay coefficient of variation was $10.5 \%(n=10)$. The recovery of angiotensin I added to superfusate was $85 \pm 2 \%(n=10)$. To rule out the presence of other serine proteases active at neutral $\mathrm{pH}$, the same kallikrein-stimulated samples and control samples were assayed in the presence and absence of $5 \mu \mathrm{l}$ of the serine protease inhibitor, phenylmethyl sulfonylfluoride $(5 \%$ in ethanol). There was no significant difference in angiotensin I generation by the addition of phenylmethyl sulfonylfluoride $(r=0.98, P<0.01, n=10)$. Therefore, we did not use phenylmethyl sulfonylfluoride in the experiments. The results of the experiments are expressed as the percentage increase over the base-line renin release after each stimulation. Statistical analysis was performed using the paired $t$ test with $\log$ transformation. Significance was defined as $P$ value of $<0.05$. To rule out that the increased renin concentration in the kallikrein superfused samples was due to activation of inactive renin, present in the nephrectomized plasma by kallikrein, the samples were incubated with synthetic tetradecapeptide $(50 \mathrm{ng} /$ tube, Boehringer Mannheim Biochemicals, Indianapolis, Ind.) instead of nephrectomized rat plasma.

Acid activation of renin. 1-ml sample of superfusate or rat plasma was dialyzed for $24 \mathrm{~h}$ at $4^{\circ} \mathrm{C}$ against glycine- $\mathrm{HCl}$ buffer at $\mathrm{pH} 3.3$, then dialyzed against sodium phosphate buffer at $\mathrm{pH} 7.4$ for a further $24 \mathrm{~h}$. Renin concentration was then measured as described in the preceding section.

Determination of molecular weight of renin. $10 \mathrm{ml}$ of superfusion sample was lyophilized and resuspended in $1 \mathrm{ml}$ of $0.05 \mathrm{M}$ Tris-chloride buffer, $\mathrm{pH}$ 8.0, which also contained $0.05 \mathrm{M} \mathrm{HaCl}$ and $0.2 \% \mathrm{NaN}_{3}$, and was applied to a Sephacryl $\mathrm{S}-200$ column $(1.5 \times 90 \mathrm{~cm}$; void volume $56.7 \mathrm{ml})$. The column was eluted with $0.05 \mathrm{M}$ Tris-chloride buffer, pH 8.0, which also contained $0.05 \mathrm{M} \mathrm{NaCl}$ and $0.2 \% \mathrm{NaN}_{3}$. 1-ml fractions were collected and assayed for angiotensin I generating activity. This column was calibrated with bovine serum albumin $(67,000 \mathrm{~mol} \mathrm{wt})$, ovalbumin $(45,000 \mathrm{~mol} \mathrm{wt})$, chymotrypsinogen A $(25,000 \mathrm{~mol} \mathrm{wt})$, and cytochrome $\mathrm{C}(12,400$ mol wt). A plot of the ratio of the elution volume/void volume ( $\mathrm{Ve} / \mathrm{Vo})$ vs. the log of molecular weight of the standards generated a straight line for estimation of the molecular weight of renin.

\section{RESULTS}

Fig. 1 shows the elution of TAME esterase activity after DEAE-Sephadex column chromatography. Two peaks, $A$ and $B$, of esterase activity are present and the B component is RUK (11). The B fraction also demonstrated kininogenase activity because it caused contractions of the rat uterus in the presence of dog plasma kininogens. In this fraction, the ratio of kinin generating activity (micrograms bradykinin equivalents generated per minute) to TAME esterase activity in the colorimetric assay (micromole per TAME hydrolyzed per minute) was 2.18. 73 and 134 esterase units of $A$ and $\mathrm{B}$ components, respectively, were obtained from the urine of 50 rats. The dose response of renin release to kallikrein stimulation is presented in Fig. 2. Stimulation was significant above $70 \mathrm{mEU} / \mathrm{ml}$. Re- 


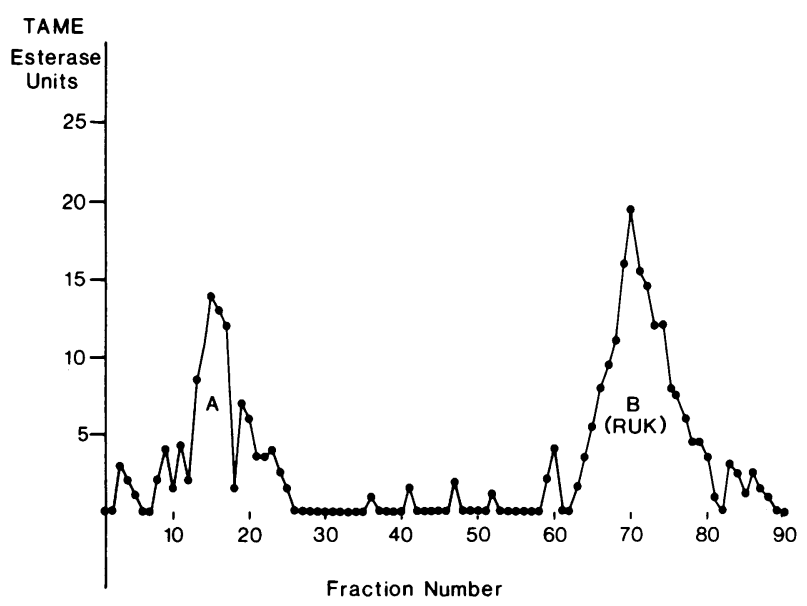

FIGURE 1 DEAE Sephadex column chromatography. TAME esterase activity of elution samples after DEAE-Sephadex column chromatography showed two large peaks. Peak B contains RUK.

peated doses of kallikrein showed similar stimulation and the base line returned to control levels after stimulation with kallikrein (Fig. 3). The values of glutamic oxaloacetic transaminase and $\gamma$-glutamyl transpeptidase were not different in the control and kallikrein-stimulated samples.

To test the possibility that kallikrein acts in the test tube instead of renal tissue, the effects of adding RUK to control superfusion samples were evaluated. The direct addition of kallikrein at doses of 3.5, 35, and 350 $\mathrm{mEU} / \mathrm{ml}$ to control superfusate samples did not cause

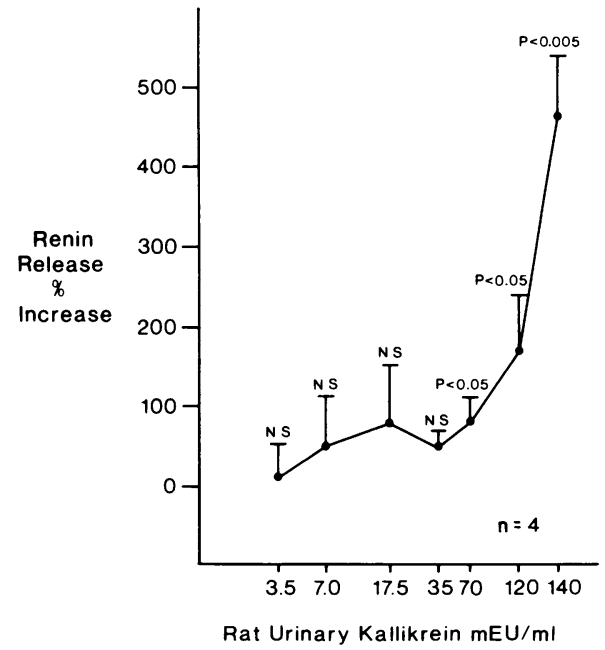

FIGURE 2 Effect of kallikrein on renin release. Effect of RUK (3.5 to $140 \mathrm{mEU} / \mathrm{ml}$ ) on renin release from rat renal cortical slices was evaluated. 70 to $140 \mathrm{mEU} / \mathrm{ml}$ of RUK-stimulated the renin release significantly in a dose-dependent fashion. The percent increase is shown on the ordinate and the dose of kallikrein is shown in a log plot on the abscissa.

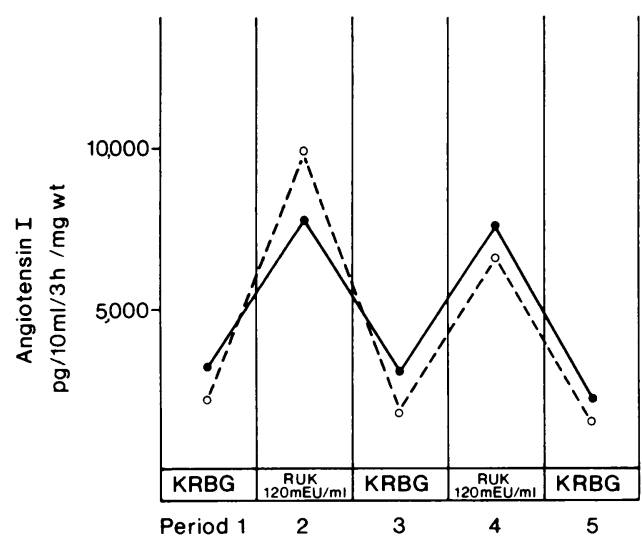

FIGURE 3 Effect of kallikrein on renin release. Effect of RUK $120 \mathrm{mEU} / \mathrm{ml}$ on renin release from rat renal cortical slices was evaluated. Period 2 and 4 are stimulated by kallikrein and period 1,3 , and 5 are control. After stimulation, the renin level (period 3 and 5) returned to control level (period 1).

any significant increase of renin concentration as compared with control superfusate. To test the possibility that kallikrein (or some enzyme released from the kidney tissue) might be activating inactive renin in the nephrectomized rat plasma during the renin assay, we used the synthetic tetradecapeptide as the source of angiotensinogen. When the renin assay of the kallikreinstimulated samples was performed using tetradecapeptide instead of nephrectomized rat plasma in the same sample, there was no significant difference in the percent increase of renin release $(\mathrm{RUK} 140 \mathrm{mEU} / \mathrm{ml}$ and nephrectomized rat plasma caused $483 \pm 65 \%$ increase, and RUK $140 \mathrm{mEU} / \mathrm{ml}$ + tetradecapeptide, $50 \mathrm{ng} / \mathrm{tube}$ caused $411 \pm 81 \%$ increase). Therefore, kallikrein must be acting directly on renal tissue to release renin. Furthermore, nephrectomized rat plasma had no detectable renin activity and was also not activated by acid treatment and subsequent incubation with 140 $\mathrm{mEU} / \mathrm{ml}$ of RUK for $1 \mathrm{~h}$ at $25^{\circ} \mathrm{C}$.

Fig. 4 shows the effects of trasylol on renin release. $120 \mathrm{mEU} / \mathrm{ml}$ of RUK increased the renin release by $172.2 \pm 72.4 \%$ and inhibition of this increase occurred with 472 kallikrein inhibiting units $/ \mathrm{ml}$ of trasylol. RUK was more potent than maximal stimulating doses of prostaglandin $\mathrm{E}_{2}(0.1 \mathrm{mM})$ which caused a percentage increase of renin release of $(170 \pm 43 \%, n=4)$ and equal or more potent than $5 \mathrm{mM}$ dibutyryl cyclic AMP $(272 \pm 40 \%, n=4)$ or $0.8 \mu \mathrm{M}$ isoproterenol $(242 \pm 49 \%$, $n=4$ ), but the data were not significantly different.

Because kallikrein can generate bradykinin and bradykinin stimulate prostaglandin production, which in turn can stimulate renin release, the effect of bradykinin on renin release from rat renal cortical slices was evaluated (Fig. 5). Doses of bradykinin from $0.1 \mu \mathrm{M}$ to $0.1 \mathrm{mM}$ did not stimulate renin release. Fig. 6 shows the effects of trypsin on renin release from 


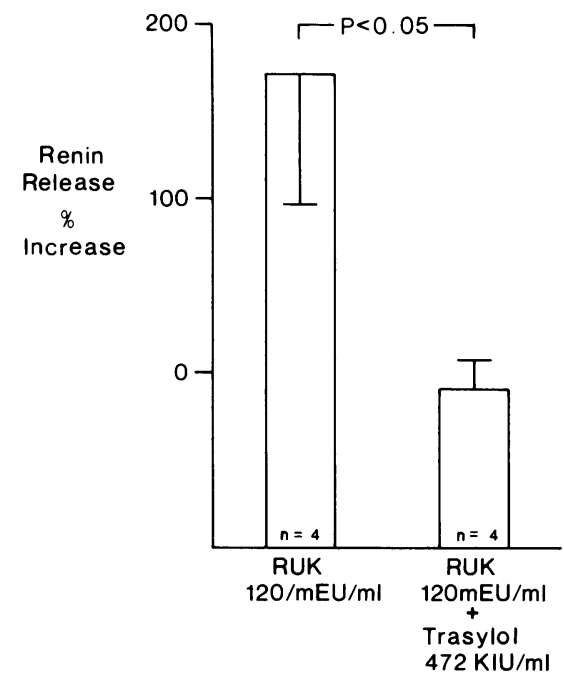

FIGURE 4 Effect of trasylol. RUK $120 \mathrm{mEU} / \mathrm{ml}$ stimulated the renin release $172.2 \pm 72.4$. Trasylol, a kallikrein inhibitor, 472 $\mathrm{KIU} / \mathrm{ml}$ completely abolished the action of $120 \mathrm{mEU} / \mathrm{ml}$ of RUK.

rat renal cortical slices. No stimulation was seen with concentration from $1 \mathrm{nM}$ to $6 \mu \mathrm{M}\left(23-138 \times 10^{3}\right.$ $\mathrm{mEU} / \mathrm{ml}$ ). Acid treatment of the superfusate did not increase the renin concentration from either basal or kallikrein-treated kidney slices, indicating the absence of acid activatable renin.

Sephacryl column chromatography of basal and kallikrein-stimulated samples showed only one broad peak of angiotensin I generating activity (Fig. 7). The apex of this fraction was fraction 91 , which corresponded to molecular weight, $\sim 40,000$, using the calibration curve in Fig. 8. There were no significant differences in the elution profile between basal and kallikrein-stimulated renin samples.

\section{DISCUSSION}

There is considerable evidence to indicate that renal renin is largely in the form of a prorenin or inactive

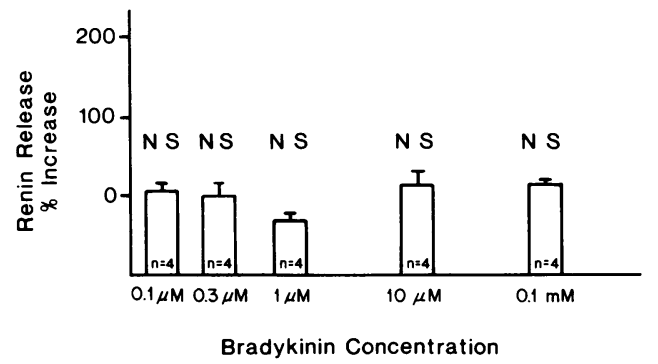

FIGURE 5 Effect of bradykinin. Effect of bradykinin $(0.1 \mu \mathrm{M}$ to $0.1 \mathrm{mM}$ ) on renin release was evaluated using superfusion experiment. There was no increase of renin release by bradykinin.

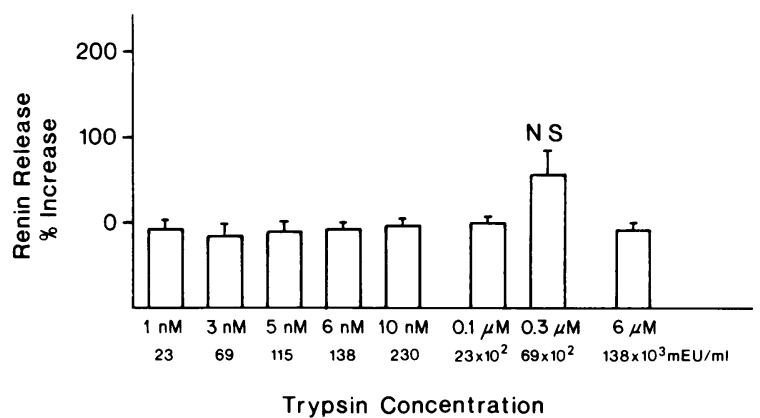

Figure 6 Effect of trypsin. Effects of trypsin ( $1 \mathrm{nM}$ to $6 \mu \mathrm{M}$ ) on renin release was evaluated using superfusion experiment. There was no increase of renin release by trypsin. The comparable TAME esterase units are shown below the molar concentration.

form $(16 ; 17)$. This prorenin is mainly of molecular weight of 60,000. However, other large molecular weight renins are also present. In man, both high and low molecular weight renin are secreted. In human plasma, the conversion of inactive renin to active renin has been accomplished by acid $(18,19)$, trypsin $(20)$, or cold $(21,22)$ treatment of plasma, and more recently by the addition of the proteolytic enzyme kallikrein $(6,23)$. Furthermore, Inagami et al. $(24,25)$ has reported the activation of purified high molecular weight renin of plasma and kidney by kallikrein. It is still controversial whether the activation of inactive (high molecular weight) plasma renin converts the inactive renin to the low molecular weight renin. In view of the fact that kallikrein can activate renin, the suggestion

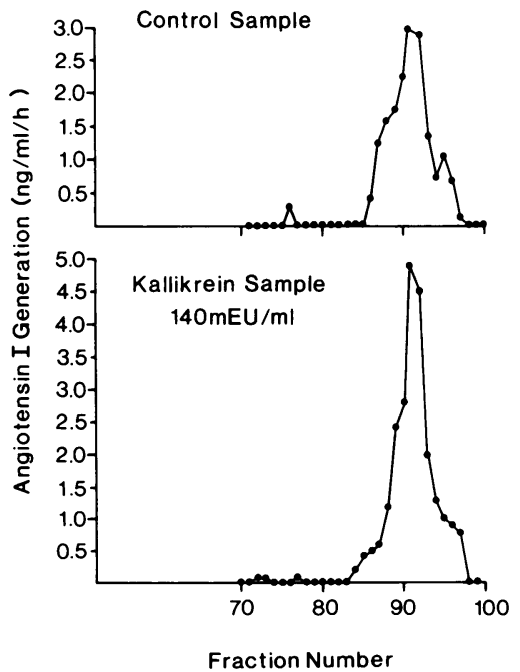

Figure 7 Elution profile of Sephacryl S-200 column. Elution profile of angiotensin I generating activity (renin concentration) of control superfusate (top panel) and kallikrein-stimulated superfusate (bottom panel) are shown. There were no major differences in the elution profile between the two samples. 


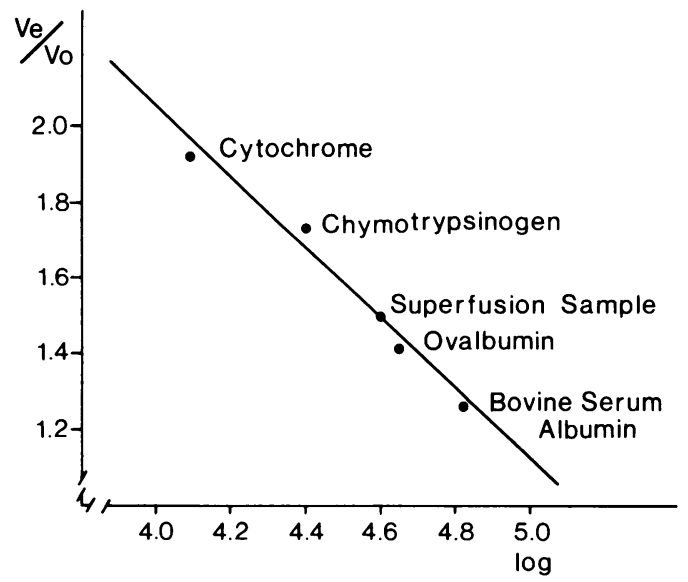

Figure 8 Calibration curve of Sephacryl S-200 column for molecular weight measurement. On the ordinate, the ratio of the elution volume ( $\mathrm{Ve}$ ) of different standards over the void volume (Vo) is shown. The log of the molecular weight is shown on the abscissa. The superfusion samples eluted between chymotrypsinogen and ovalbumin and had an estimated molecular weight of 40,000 .

has been made that renal kallikrein may convert the inactive pro-renin to active renin intrarenally. This hypothesis is attractive because renal kallikrein is made in the renal cortex, especially near the juxtaglomerular apparatus (10). Furthermore, a similar role for kallikrein in conversion of proinsulin within the beta cell of the pancreas has been proposed $(26,27)$.

Our studies provide support for this hypothesis. Kallikrein directly stimulated renin release from the superfused kidney slices and this release was blocked by a specific inhibitor of kallikrein, trasylol. This release due to kallikrein did not appear to be due merely to tissue damage and leakage of renin from the renal slice, since repeated doses of kallikrein showed similar stimulation and base line returned to control levels after stimulation with kallikrein. Furthermore, the concentrations of the tissue enzyme glutamic oxaloacetic transaminase and $\gamma$-glutamyl transpeptidase that usually increases when there is tissue damage was not significantly different in the control and kallikrein-stimulated samples. Also trypsin, another potent proteolytic enzyme did not release renin. That the action of kallikrein was not via bradykinin production is suggested by the fact that bradykinin did not stimulate renin release. We also ruled out the possibility that kallikrein merely converted prorenin to active renin while in contact with the perfusate. The addition of kallikrein to control superfusate, that is, after the superfusate had perfused the kidney, did not increase renin activity. Therefore, the rat kidney appears to release only active renin because acid activation also did not increase renin concentration. Furthermore, Sephacryl S-200 column chromatography of the superfusate from basal and kallikrein-stimulated samples revealed only one peak of active renin, $\sim 40,000 \mathrm{~mol}$ wt. Inagami et al. (16) reported that rat kidneys contain high molecular weight renin that is readily converted to the low molecular weight renin by renal proteases. Kallikrein is a potent stimulator of renin release since the response to kallikrein was significantly greater than that of prostaglandin $E_{2}$ and equal to or greater than the response to dibutyryl cyclic AMP and isoproterenol. Our data, therefore, support the hypothesis that kallikrein may play a role in the secretion of renin. The precise mechanism by which the superfused kallikrein stimulated renin release is not elucidated by our data. Possibly kallikrein enters the juxtaglomerular cells by pinocytosis and activates the secretory process and conversion of high molecular weight renin to low molecular weight renin or possibly it affects the cell membrane and release renin from those granules that have fused with the cell membrane in the process of secretion.

\section{ACKNOWLEDGMENTS}

The authors are grateful to Doctors J. P. Rapp, R. P. McPartland, and D. L. Sustarsic for their helpfulness in isolating rat urinary kallikrein.

The study was supported in part by National Institutes of Health grant HL-19644.

\section{REFERENCES}

1. McGiff, J. C., N. A. Terragno, K. U. Malik, and A. J. Lonigro. 1972. Release of prostaglandin E-like substance from canine kidney by bradykinin. Circ. Res. 31: 36-43.

2. Zusman, R. M., and H. R. Keiser. 1977. Prostaglandin biosynthesis by rabbit renomedullary interstitial cells in tissue culture. Stimulation by angiotensin II, bradykinin, and arginine vasopressin. J. Clin. Invest. 60: 215-223.

3. Larsson, C., P. Weber, and E. Anggard. 1974. Arachidonic acid increases and indomethacin decreases plasma renin activity in the rabbit. Eur. J. Pharmacol. 28: 391-394.

4. Yun, J., G. Kelly, F. C. Bartter, and H. Smith. 1977. Role of prostaglandins in the control of renin secretion in the dog. Circ. Res. 40: 459-464.

5. Franco-Saenz, R., S. Suzuki, S. Y. Tan, and P. J. Mulrow. 1980. Prostaglandin stimulation of renin release: independence of $\beta$-adrenergic activity and possible mechanism of action. Endocrinology. 106: 1400-1404.

6. Sealey, J. E., S. A. Atlas, J. H. Laragh, N. B. Oza, and J. W. Ryan. 1978. Human urinary kallikrein converts inactive to active renin and is a possible physiological activator of renin. Nature (Lond.). 275: 144-145.

7. Nustad, K. 1970. Localization of kininogenase in the rat kidney. Br. J. Pharmacol. 39: 87-98.

8. Scicli, A. G., N. B. Oza, and O. A. Carretero. 1974. Distribution of kallikrein in the kidney. Physiologist. 17: 327. (Abstr.)

9. Carretero, O. A., and A. G. Scicli. 1976. Renal kallikrein: its localization and possible role in renal function. Fed. Proc. 35: 194-198.

10. Ostavik, T. B., K. Nustad, P. Brantzaeg, and J. V. Pierce. 1976. Cellular origin of urinary kallikrein. J. Histochem. Cytochem. 24: 1037-1039.

11. Nustad, K., and J. V. Pierce. 1974. Purification of rat 
urinary kallikreins and their specific antibody. Biochemistry. 13: 2312-2319.

12. Roberts, P. S. 1958. Measurement of rate of plasmin action on synthetic substrate. J. Biol. Chem. 232: 285-291.

13. Nustad, K. 1970. The relationship between kidney and urinary kininogenase. Br. J. Pharmacol. 39: 73-86.

14. Henry, R. J., N. Chiamori, O. J. Golub, and S. Berkman. 1960. Revised spectrophotometric methods for the determination of glutamic oxalacetic transaminase, glutamic pyruvic transaminase and lactic dehydrogenase. Am. J. Clin. Pathol. 34: 381-398.

15. Szasz, G. 1969. A kinetic photometric method for serum y-glutamyl transpeptidase. Clin. Chem. 15: 124-136.

16. Inagami, T., S. Hirose, K. Murakami, and T. Matoba. 1977. Native form of renin in the kidney. J. Biol. Chem. 252: 7733-7737.

17. Slater, E., and E. Haber. 1976. A large form of renin from normal human kidney. Circulation. 53/54 (Suppl. II): 143. (Abstr.)

18. Lumbers, E. R. 1971. Activation of renin in human amniotic fluid by low pH. Enzymologia. 40: 329-336.

19. Day, R. P., and J. A. Leutscher. 1974. Big renin: a possible prohormone in kidney and plasma of a patient with Wilms Tumor. J. Clin. Endocrinol. Metab. 38: 923-926.

20. Cooper, R. M., G. E. Murray, and D. H. Osmond. 1977.
Trypsin-induced activation of renin precursor in plasma of normal and anephric man. Circ. Res. 40(Suppl. I): $171-179$.

21. Osmond, D. H., L. J. Ross, and K. D. Scaiff. 1973. Increased renin activity after cold storage of human plasma. Can. J. Physiol. Pharmacol. 51: 705-708.

22. Sealey, J. E., and J. H. Laragh. 1975. "Prorenin" in human plasma? Circ. Res. 36/37 (Suppl. I): 10-16.

23. Derkx, F. H. M., H. L. Tan-Tjinog, A. J. Manin't Veld, M. P. A. Schalekamp, and M. A. D. H. Schalekamp. 1979. Activation of inactive plasma renin by tissue kallikrein. J. Clin. Endocrinol. Metab. 49: 765-769.

24. Inagami, T. 1979. Recent development in the biochemistry of renin. Jpn. Heart J. 20: 762-763.

25. Inagami, T., N. Yokosawa, S. Hirose, Y. Takii, and N. Takahashi. 1979. Evidence for completely inactive renin zymogen and its activation by kallikreins. XIth Int. Congr. Biochem. 11: 670. (Abstr.)

26. ole-Moi Yoi, O., G. S. Pinkus, J. Spragg, and K. F. Austen. 1979. Identification of human glandular kallikrein in the beta cell of the pancreas. N. Engl.J. Med. 300: 1289-1294.

27. ole-Moi Yoi, O., D. C. Seldin, J. Spragg, G. S. Pinkus, and K. F. Austen. 1979. Sequential cleavage of proinsulin by human pancreatic kallikrein and a human pancreatic kininase. Proc. Natl. Acad. Sci. U. S. A. 76: 3612-3616. 